\title{
庭園の背後思想と構成に関する研究 (XI)
}

夢空国師と永保寺庭園の構成について（その 2)

澤 田 天 瑞*

\author{
A Study on the Japanese Gardens Viewed from the Teachings of the \\ Rinzai Zen Buddhism (XI)
}

- Case Study on the Eihōji Garden, Gifu (No. 2) -

\section{by Tenzui SAWADA*}

\section{1. 序 論}

本研究の目的は，岐阜県多治見市にある虎溪山永保寺 庭園の作庭構成とその表現内容を夢空国師の「夢中問答」 に基いて，思想的に解明しょうとするものである。永保 寺は臨済宗南禅寺派の禅寺で, 正和 2 年 (1313) に夢空 国師が開創した古彩庵を前身とし，のちに仏德禅師の門 下に移譲して虎溪山永保寺と改名されたものである。庭 園は観音堂を中心に，自然の岩壁を巧みに利用して瀑泉 となり池泉に注いでいる。池泉は 3 個所にあって, 北部 の大池泉には中央に大きく廊橋を架け，3 個所に中島を 配した面積約 9, $240 m^{2}$ の迴遊式築山林泉庭園である。

本庭園は，古奚俺開祖夢空国師が，悟道後の「長荃の 工夫」のため，庭園の主題を「臨済録」から「臨済禅の

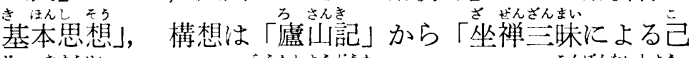
事の究明」・構成は「永嘉証道歌」に基いて「根本内証の 境界」を表現した，廻遊式築川林泉の臨済宗禅林庭園で あると考察した。

前論に沶いて，本庭園の主題である「臨済禅の基本思 想」を「臨済録, 序」の「院臨古渡, 運済往来。把定要 津，壁立万仞。奪人奪境，陶鋳仙陀。三要三立，鈴鎚衲 子。常在家舍, 不離途中。無位真人, 面門出入。両堂斉 喝, 賓主歴然。照用同時, 本無前後。菱花対像, 虚谷伝 声。妙応無方, 不留朕逊。」(大正新修大蔵経第 47 巻, $\mathrm{P}$ 496）之，「臨済録，臨済慧照禅塔記」（大正新修大蔵経 第47巻，P506）の故事に基いて考察した。構想である 「莝禅三昧による己事の究明」については，「盧山記」

（大正新修大蔵経第51巻，P 1025）に紹介された盧山の 地勢と由来汇基いて，本庭園の地割に配当し，その関係 を照合して考察した。

本論に括いては，本庭園の構成である「根本内証の境 望」を「永嘉証道歌」(大正新修大蔵経第48巻 P 395) に 基いて考察することとしたい。

\section{2. 庭園の構成}

* 澤田庭園研究所長
本庭園の構成は，「永嘉証道歌」に基いて「根本内証 の境界」を表現している。

「永嘉証道歌，(1)君不見。絶学無為閉道人。不除妄想 不求真。無明実性即伀性。幻化空身即法身。法身覚了無 一物。本源自性天真仏。五除浮雲空去来。三毒水泡虚出 没。証実相無人法。刹那減却彻阿鼻業。若将妄語䚺竟 生。自招抜舌塵沙劫。頓覚了如来禅。六度万行体中円。 夢裡明明有六趣。覚後空空無大千。無罪福無損益。寂減 性中莫問䆓。比来塺鏡未曽磨。今日分明須培折。2誰無 念誰無生。若実無半無不生。喚取機関木人問。求仏施功 早晚成。3 放四大莫把捉。寂減性中随飲㰷。諸行無常一 切空。即是如来大円覚。決定説表真僧。有人不肯任情 徵。直截根源仏所印。摘葉尋技我不能。摩尼珠人不識。 如来蔵裡親収得。六般神用空不空。一顆円光色非色。 (4)浄五眼得五力。唯証乃知難可測。鏡裡看形見不難。水 中捉月拈得。氞常独行常独步。详者同遊涅綮路。調古神 清風自高。貌頛骨剛人不顧。無価珍用無尽 ${ }^{\circ}$ 利物応縁終 不恡。三身四智体中円。八解六解心地印。(6)土一決一 切了。中下多聞多不信。但自懐中解坧衣。誰能向外誇精 進。従他謗任他非。把火焼天徒自疲。我聞恰如飲甘露。 銷融頓入不思議。観悪言是功徳。此則成吾善知識。不因 訕起怨親。何表無生慈忍力。 7 宗亦通説亦通。定慧门明 不滞空。非但我今独详了。恒沙諸仏体皆同。獅子吼無畏 説。百獣聞之皆脳裂。否象奔波失彻威。天竜寂聴生欣 悦。(8)遊江海涉山川。尋師訪道為参禅。自従認得曹谿 路。了知生死不相関。行亦禅坐亦禅。語㷛動静体安然。 縦遇鋒刀常坦坦。仮鐃西薬也間間。我師得見然灯仏。多 劫曹為忍唇仙。(9)幾回生幾回死。生死悠悠定止。自然頓

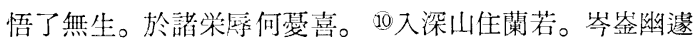
長於下。優遊静坐野僧家。閴寂安居実㴧泗。覚則了不施 功。一切有為法不同。住相布施生天福, 猶如仰箭射虚 空。勢力尽箭僄阥。招得来生不如意。争似無為実相門。 11一超直入如来地。但得本莫愁本。如浄瑠璃含宝月。我 今解此如意珠。自利利他終不歇。江月照杉風吹。永夜清 霄何所為。仏性戒珠心地印。霧露雲霞体上衣。降竜鉢解 虎錫。両鉆金環鳴歴歴。不是標形虚事持。如来宝杖親㻊 
"跡。的不求真不断妄。了知二法空無相。無相無空無 不 空。即是如来真実。心鏡明鑑無碍。廓然瑩徹周沙界。万 象森羅影現中。一顆円光非内外。豁達空揆因果。13莽莽 蕩蕩招殊禍。棄有著空病亦然。還如避滒而投火。唅妄心 取真理。取捨之心成巧偽。学人不了用修行。真成認賊将 為子。損法財隇功德。莫不由斯心意識。是以禅門了却 心。頓入無生知見力。四大大夫乗慧剣。般若鋒分金剛 焰。非但能摧外道心。早兽落却天魔胆。震法雷撃法鼓。 布慈雲兮酒甘露。竜象踣蹋潤無辺。三乗五性皆醒悟。

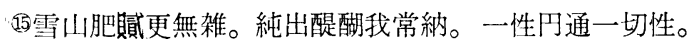
一法徧含一切法。一月普現一切水。一切水月一月摂。 16諸仏法身入我性。我性還与如来合。一地具定一切地。 非色非人非行業。弾指円成八万門。刹那隇却三祇劫。一 切数句非数句。与吾霊覚何交涉。听不可毁不可讃。体若 虚空勿涯。不離当処常湛然。18覚則知君不可見。不可得 中只䐴得。19黙時説説時黙。大施門開無墾塞。有人間我 解何宗。報道摩訶般若力。或是或非人不識。逆行順行天 莫測。吾早兽経多劫修。不是等閑相註惑。20建法幢立宗 旨。明明仏刺曹谿是。第一迦葉首伝灯。二十八代西天 記。歴江海入此土。菩提達磨為初祖。六代伝衣大下聞。 後人得道何窮数。21真不立妄本空。有無俱遺不空空。二 十空門元下着。一性如来体自同。心是根法是塵。両種猶 如鏡上痕。痕砛尽除光始現。心法雙亡性則真。2差末法 覀時世。臬生薄福難調制。去聖遠分邪見深。魔強法弱多 怨書。聞説如来頓教門, 恨不隇除令瓦砕。作在心㱠在 身。不須怨訴更尤人。欲得不招無間業。莫謗如来正法 輸。23称檀林無雑樹。樊密深沈獅子住。境静 林間独自 遊。走獣飛禽皆遠去。獅子児臬随後。三歳便能大哮吼。 若是野干逐法王。百千妖怪虚閉口。円頓教筂人情。有疑 不決直須争。不是山僧湜人我。修行恐妵断常坑。2非不 非是不是。美之毫幣失千里是則竜女顿成仏。非則善星生 陷墜。2 吾早年来程学問。亦兽討疏尋経論。分別名相不 知休。入海算沙徒自困。欲被如来苦呵責。数他珍宝有何 益。従来蹯蹬覚虚行 ${ }^{\circ}$ 多年拄作風塵客。種性邪錯知解。 不達如来円頓制。二乘精進無道心。外道聡明無智慧。亦 思瘼亦小黖。空奉指上生実解。執指為月抂施功。根境 法中虚揑怪。不見一法郎如来。广得名為観自在。了則業 障本来空。未了還貧償宿俵。飢逢王膳不能喰。病遇医王 争得将。在欲行禅知見力。火中生蓮終不填。勇施犯重悟 無生。早時成仏于今在。28椚了吼無畏説。深媄戃憧項皮 靬但知犯重障菩提。不見如来閒䟤訣。有二比丘犯媱殺。 波離篮光增罪結。維摩大士頓除疑。猶如赤日銷霜雪。 30不思議解脱力。妙用恒沙也無極。四事供荃敢辞労。万 両黄金亦銷得。粉骨挽身未足酬。一句了然超百億。法中 王最高勝。河沙如来同共証。我今解此如意珠。信受之者 皆相応。了丁見無一物。亦無人分亦無仏。大千沙界海中 漚。一切賢聖如払。仮使鉄輪頂上旋。定慧円明終不失。 31日可冷月可熱。衆魔不能壊真説。象駕㟊㟳謾進途。誰
見蟐螂能拒轍。大象不遊於兔径。大悟不拘於小節。莫将 管見謗蒼蒼。末了吾今為君決。」（大正新修大蔵 経 第 47 巻)

（通釈）(1)諸君，是非善悪の分別を超越し，悟道を得 て絶対の境地に生きる，すばらしい人生のあることを知 っているか。仏道修行の第一歩は先ず妄想を除き真理を 求めることにあるが，この境地に達した人は相対的な差 別から離れて，除くべき妄想も求めるべき真理もない。 無明が即ち仏性であることを自覚するならば，その身そ のまま法身であり仏ではないか。諸君は自我といら泡沫 のような貧買癡の三毒や，心身を構成する色受想行識の 五陰に執着して本性に気がつかずにいる。いま真理を把 握し一切の自我を捨てるならば，阿鼻地獄に落らる罪悪 は直ちに消隇してしまう。これは私自身の体験でいうこ とで嘘や方便でいうのではない。諸君自身が本来清浄心 であるという自覚を持つといらことが，とりもなおさず 如来禅を悟ることである。永年に亘り六波羅密を修行し て悟りに到る手間もいらず，乙かも一切の六波羅密はこ とごとく如来禅の中に具っている。古今東西のあらゆる 出来事を見てもすべて夢の夢であり，妄想の作り出した 幻影にすぎないし，一旦夢から醒めて見ればこの世の中 は空虚であって何にもないではないか。諸君が恐れてい る地獄に落らて罪苦を受けることも，極楽に生れて福業 を招ねくこともないし，不生不隇の湜槃寂隇のところに 罪福を求めても，それは無䭾ではないか。凡夫は應の積 った鏡のように，妄想の執着でこれを自覚せずにいる。 いまや諸君も時節が到来して仏祖正伝の仏法を聞くこと ができたから，自己本来具っている仏性の光を磨きだす ベきである。

(2)人間は悟たからとて木石のように何にも思考せ欧も のでもないし，涅槃寂缄の境地に到達したからといって 生死を免れるわけでもない。それでは一体何を指して無 念といい，誰れを呼んで無生というのか。もし，宇宙全 体が無生であるならば，無生といら名も立た㰠わけであ る。同様汇無念であるなら代無念ということも立た好 けである。しかし，無念の念，無生の生ということは， 単なる理窟では判らないし，実際に体験して見なければ その妙処を会得することもできない。結局，支字で表せ るところではないから，諸君自身に間らて見よ。これを 実参工夫といって他に向って求めるものではない。諸君 が成仏するために悟を開こうとして学問修行の功を積ん でいては，いつまでたっても開悟成仏の時期は到来しな い。月の如く無我無心になって一切の妄想分別を離れて しまえば，たちどころに生死即涅槃の事実を手にするこ とができるであろら。

(3)一切の万物が四大の仮和合であってみれば，和合は いつ解消して離散するかも知机ないから, 自分の肉体す ら当てにできない。一切の万物, 諸法は因縁によるもの 
であるから，無常，無我，空の道理を知らずに我見を立 てるから，そこに苦を生じて現実の矛盾に苦しみ絁むの である。そこで生死といら妄想分別を離れてしま劣ば, 生きる之きには徽底的に生き死始之きは徽底的に死邓。 このように妄想煩悩を隇却させたところに涅幣寂静の境 地がある。現実と理想とを同一視するといら実相印が, 仏の広大で円満な悟りの心である。この真理は決定して 不動のものであり, この真理を人に知らし, 機に応じて 説くのが仏教であり，伝導教化するのが真実の僧の役目 である。私㤝六祖慧能からこの決定の説を相続している から，決定の真理，正伝の仏法について疑義のあるもの は，遠虑なく質問するがよい。諸君，煩悩を断って菩提 を得よらなどといらことは枝葉末節のことで，仏陀もそ のような考へは扮許しにならないし，私も容赦はしな い。凡夫は仏性という如意珠が心中にあることに気がつ かず色に迷い声を聞いて執着するから，煩悩の塵や恬に 覆い隠されて実体が見觉ないだけのことである。

(4伀性という如意珠を識得するには，信仰力，精神 力, 正念力, 禅定力, 智恵力の五力と, 真実性を見透せ る五眼の法力を見えることが必要である。この五力と五 眼は自から体得すべき法力であり，心眼さ兄開けばでき ることであるが，世間の学問や情識の分別では会得する ことはむずかしい。凡夫は幻影汇迷い仮相に執着して取 捨僧愛の二見に涉るから，猿が水中の月を捉えようとし て水に溺れるよらな愚を演ずるのである。これは仏性が 本来無相であるから，智解分別の心意識では捉えること ができないといら譬えである。

(5仏性の如意珠を得た人の境地は，涅槃の大道を思う ままに遊戯分遙されている。これらの人が提唱寸る仏法 は一点の鷹垢煩悩もなく格調も高尚であるが，その容貌 はやせて贅肉はなく，骨格は剛堅で精神的に凡人と異な るところがあるから，世人は誰れも顧りみずこれも常化 独り行き独り歩す所以で㐫る。私は仏道といら無形の財 宝を豊富に持っているから，物質的に㤝笨して幣衣粗 服を着ているが，精神的には裕富である。有形の富は際 限が满るが，私の持っている無価の富はいくら施しても 尽きるといら要いはない。使光将使う汪ど增加するとい ら宇宙第一の宝である。この無価の宝とは大円鏡智, 平 等性智, 妙観察智, 成所作智の四智をはじめ, 八解脱, 方神通を心中に具有することで岁る。

(6)上智上根の者は，一度び道を聞けば直ちに決定して 信解行証するが，中根と下根の者は多くの読書して多く の仏説を聞いても，自己の智見解会に惑わされて悟道す ることができず，また，悟道佳するに遅いものであ る。私泣六祖慧能より伝兄られた正法を布教するに当っ て, 種々の誹謗や迫害に遭遇しょうとも, 敢然として所 信を断行し，大信決定の境地を披歴するものである。私 は誹謗を聞いても腹を立てるぞころか，天の甘露水を飲
むような気持ちがする。誹謗は場合によっては反って精 神力を增し, 或は忍耐力を養うことになるから, 誹勏に 対して怨むこともなく，褒められたからといって特に親 しくする必要もない。

(う)真に道を体得した境地の人は，戒定慧の三学といっ て定慧と戒律の二道に通じていなければならない。共に 戒律を守ることは仏道修行者として久くべからざる要件 である。これは私だけの独善的な考えでなく，三世の諸 仏方も皆定慧之戒律の妙境達しておられるのを身ても 明白である。獅子注百獣の王と称し，一切の動物に対し て少しも怖れることをしない。獅子が一度び吼壳るとき 百獣はその声を聞いて震光上り，象の如き大力の獣も平 常の威信を失ってしまう。ただ独り天竜だけは静かに獅 子の伒えるのを聞いて，眼を細くし喜びの心を生ずると いら。中下根で多聞の教家の人達は驚くであろらが，私 をはじめ天下達識の上士は六祖大師の正法, 本来無一物 の禅風を喜んで信解し，これを護持することであろう。

(8)私は明師を求めて各地を遍歴し, 遂に曹溪山の六祖 大師に扮目に掛り, 生死即無生, 無常即無速の一大事を 悟ったが，真の活禅というものは，坐して静かに虑ばか れば自ずと仏の智恵が生じ，生死の中にあって生死に心 が静摇せず, 行住坐臥, 語黙動静の間, 常に寂然不動の 大禅定を離れ好ものである。かくの如く仏祖の真禅を得 て生死の関門を透脱すれば，鋒刀や毒薬も清風明月とな んぞ買ならんやといら境地をいらのである。

(9)幸い沈る，私達は人間界に生活しているものの，死 後の世界は予想もつかない。現世の業力で生死流転を未 来永劫に繰り返し, 所を定めて止まる訳にはゆかぬもの である。これは前生後生を通じての輪呬のことをいった ものではなく，喜怒愛楽などはすべてが貧矌䂏の迷いの 心から生じたものである。迷いの惑によって業をつく り，業によって苦果を招くことを繰り返している。特に 生に執着し，死を厭うことが最大の迷いの根本となって いる。私は六祖大師に参じて生死即無生の理を会得し, 生死実相を自覚してからは, 奀悲苦悩の事に心を動かす ようなことはなくなった。

1身体はたと光市井の煊噪の中にあっても，生死を透 脱して毁誉柿眨，恶悲苦㥗に心が動じない人ならば，深 山幽谷に静坐すると何んら変らない心境に住むことがで きる。この身は本来成仏であると悟った人は，多くの方 便を用いなくても，すぐさま仏祖正伝の如来禅に到達す ることができる。その理由は方便の為に立てた法門や妄 想分別で作為したものと異なるからである。果報を得る ために物を施せば，功徳によって福報を受けるであるら が，有為の福であるから限りがある。かかる有為転変の 福報よりも，無為実相の法門によって直ちに仏報広大の 功德を収めた活らがいではないか。仏教八万四千の法門 も結局はこの無為実相の門に入らせようとするものであ 
る。

11伀法の根本を体得すれば，枝葉末節のことはすべて 含まれているから，何にも愁うことはない。清浄な瑠璃 の水艋に明月の影を宿すように，心が清浄で妄想分別の 應恬がなければ，菩提の覚智は年の心の上汇光明を放つ ものであり，仏法を遠くに求める必要はない。池泉の月 影は万波の上飞宿し，松風は天然の音楽を奏でているで はないか。悟りの境地汇達した人といらのは，仏と寸分 も違わ仏性の智恵と懐相が自然淇わりその仏性は 考順心となって自らを利益し，慈悲心となって他を利益 し，功徳によって一切の悪業を制する戒めとなり，戒律 を守ることによって人生を明朗化し，この世を清く明る く明珠のように輝かせるものである。このような人の修 行力と威徳が勝れているのは, 释尊をはじめとして古聖 光德の足跡を踏んで修行された結果, 神通妙用自在の働 きができるから，正法が長く伝わるのである。

凤寸で生死即無生を覚了した即心是仏の人は身心以 外汇求めるべき真実の法もなければ，断ずるべき妄想も あるわ汁がない。心眼を開いて見れば溪声は仏の説法で 㐫り, 山の景色注仏の清浄心である。私の上う如来の 真実相を体得すれば，心性あたかも一点の塵埃も留め ず，量りもない明鏡が映像を少しも昧まさないように， 色声香味触法の六境を，西りのままに眼耳鼻舌身意の六 根に受けて妙用を現わし，秋空に一点の雲もない日本晴 れのようにわだかまりのない心となる。そして全宇宙の ありとあらゆるものが, 悉く自己の心中に包含されて, 自己とか世界とかといら相対をも離れ，宇宙法界を尽し 唯一無二の心境で劣るから，内外表裏の別もなくなっ てしまう。

四心境を泯絶したからといって, 愦って空無の見に落 ちては一種の禅病となる。この空見に落ちると神も仏も なくなり。すべてを否定して虚無思想になってしまう。 これでは世の中の秩序も道德も成立せず，迷妄を重ねて 罪悪を增して身の䙤を招く。有に執着することも病いだ が，空に住着することも病いである。いずれも大切な法 身の生命を害することは同じである。ところが，天下の 学者, 即ち仏法を学んで修行する者がこの道理を知らず 飞, 妄心を捨てて真理を求めようとしているが，そ机は 大変な䛊解であり, そのような態度で修行して, その結 果，これが真理であるような悟りを得たとしても，その 真理はやはり妄想の影法師に過ぎない。禅の工夫の主眼 はこの心意識を了却するところにあることを知って欲し い。生死即涅槃の大安心を得るには, 仏の知見の力汇上 らなければならない。

ه大丈夫たる者は, 見聞覚知の外賊のために惑され オ゙，情欲意識の内賊のために迷わされず，仏の知見の慧 剣汇よって生死即無生の実相を照破する。慧剣の威徳は 金剛の焰の如く不壊で何者にも破られず，乙かも一切の
ものを焼き尽してしまう。故に一度, 大丈夫がこの説法 をするときは外道や天魔を撃破する力が㐫る。その説法 によって一切の衆生が利益を受汁て喜ぶ様子は, 西たか も旱天に慈雨を得て草木が蘇生するよらだ。時に大丈夫 は大象が驙馬を践ったり踏んだりするように，大丈夫の 仏陀が人々を吡り飛ばしても，その声は反って多くの人 々を潤益し, 蘇生の思いをさせる妙力がある。一切衆生 がことごとく仏性であり, 本来成仏であるから仏陀の慈 悲に照らされて，無種性の人でもことごとく醒悟する。

的乳牛が雪山の香りの高い草を食べて, 純然たる醍醐 を出すように，私は如来円頓の妙法実相の法身を証得し て衆生を利益し，乙か子常恒核納受して離さない。そし て証得した円頓の妙法は吾々の本性であるからである。 吾々は自己本来具有する仏性を徹見することによって, 真如法性を証得することができる。故に一法を挙げれば 一切の万法は尽くその一法中に含蓄されて, 少しも漏れ るところはない。この我他彼此の対侍を絶した円頓無碍 の有様を, 月と水との譬えで説明しょう。天上の月は一 輪であるが，その姿は万水汇映り，汇河湖海の大より溪 澗池沼に影を落して澄濁を選ばず，小は一盆の水，細は 草の葉㯰く一滴の露といえども漏さず昧まさずに，胶 々と光をうつしている。その水月の数は実に無量である が，皆，尽く天上一輪の明月に摂入していると同じょう に, 真如法性無相の法身滩一であるが, 普く一切万法 に応じて一塵の中といえども充満して漏すところなく， また，外るところなく具わり，一切差別の万法は唯一 平等の真如法性汇摂入し, 無相の法身泡含され尽され ている。そこで，吾々が抢互いにこの妙理を悟って本具 の仏性を覚了し，宇宙の大道汇合体寸れば，凡愚の身心 がそのまま諸仏と円融一如になることができるという ものである。

『頓教の法門は修行の段階を踏まずに，すべて階級の 功德がその身湟わり，階級を超越して諸仏と同じ位い に入る。元来, 仏教汇は八万四千の法門といって, 衆生 に本来具有の妙心を悟らせるための方便手段がある。枝 葉末節の方便手段浪沟泥せずに, 根本問題を解決する のが頓教である禅の特色である。

过仏法は宇宙の真理であるから，廃仏毁釈をして寺を 燒き，僧尼を還俗させたところで，霊覚の仏法は徵動だ にしない。これを無量無碍光如来とか, 光明徧照十方世 界とか讃めたたえてみても, そんな言葉では讃歎し尽せ るものではない。何故ならば, 霊覚の本位は無限絶対で 果てしないからである。法性の真理は虚空の如く充満し ている。しかも無相であるから凡人の眼では見ることは できない。あたかも水の湛然として満ちて動かないよう に, 不変不動のものである。故にこの大道を他化求めた ら大間違いで，生死の穢土を外飞して別に涅槃の浄土が あるわけではない。 
18霊覚の本体は虚空のようなものであるから，私の師 匠の六祖慧能も，霊覚の性は一切の相を離れたものであ るから取ることができず，一切の法に即するが故に捨て ることもできないと明確にいっておられる。では，どの ようにして霊覚を悟るかといらと，得よらとも思わず， 捨てょうとも思わず，すべてが取捨憎愛の念を離れた時 に，霊覚は立ちどころに脱体現成してくるといらのであ る。この不可得の妙法は世間の演説や通俗の説教と違っ て，言端語端の及ばない代物の宣伝をするのであるか ら，普通の情識では推し測ることはできない。諸君，心 眼を開いて見よ，そして，心耳を澄して聞け，到るとこ ろに広大な法施の閒が開いているではないか。

(9この仏の大智慧光明を自から会得するのが仏道修行 の目的で，教宗でも禅宗でも，また，頓教でも漸教で も，この目的は変らないが，ただ，道を迂回するか直入 するかによって，頓漸の区別があるだけで目的は一つで ある。この摩訶般若の力を得たるのは，世間の是非善悪 に執れないから，縁に随い，機に応じて少しも滞るとい うことがない。私は実に長い、間修行した結果，この摩訶 般若の力を得たのであって，徒らに大言壮語して世人を 症かしたり，惑わせたりするものではない。

凤私が仏弟子として道場を建てて説法するのは，釈尊 の法灯である不立文字，教外別伝，直指人心，見性成仏 といら仏祖の正伝が，摩訶迦葉尊者，阿難尊者と，師匠 と弟子とか嫡々相続すること，連綿28代目の達摩大師に 至って，ついに六祖慧能に伝兄られ，私が相続して諸君 に説き聞かせている仏法である。このよう飞正伝の仏法 は少しも断絶することなく，その衣錰を相続するものが 数多くなって，私も実に六祖の衣鉢を相続した一人なの である。

22諸君，現象差別の諸法は因縁によって生じたもので ある。真といい，妄といらのも，相対上に現われた仮の 名前であって，宇宙万象を説明する上の符牉に過ぎない ものである。諸君に深遠なる空の義を悟らせようとし て，数多くの空を説いてきたが，一切を空し尽した不空 の空に体達したときに，わ秃机本具の一性，即ち，仏 性がそこに現わられてくる道理が事実として現成する。 われわれ本具の仏性は諸伀之同体同位であり，明鏡の上 うに清浄無垢で一点の痕塺を留めないものであるが，心 意識の妄想分別によって霊光がくらまされている。この 妄想分別の歴垢を払拭してしまえば，明鏡はたちまちに して本来の霊光を放つものである。このときは心法二つ ながら泿絶して，尽天尽地たた仏性の霊光のみとなるの である。

2末法の悪時世に生れ合わせた人々は，前世上り植え 来った福分が薄いために，正法を見聞してもこれを信解 行証するだけの根機もなく智慧もない。ただ，徒らに目 先きの忿望に走って，永遠の幸福の基となる種まきをし
ようとしない。釈尊入隇以来, 私まで二千年余りを過ぎ て正に末法時代となり，仏祖正伝の法も曲解が生じて害 毒を社会に流布している。しかも，わが正法の宣布を妨 害する魔説が強力である。かかる邪見の徒輩は自からが 魔境に陭落していることに気がつかず，頓悟を教える如 来の正法を説くのを聞いて，反ってこれを怪しんで正法 を壊減させようと考えている。また，それが不可能なこ とを恨みにさ思っている。このように正法を誹謗すれ ば無間地獄に落ちることを覚悟しなければならない。

及曹渓門下の禅林は萠檀林の如く, 大乗円頓の妙法を 悟了した僧は獅子王の如く，煩悩妄想の喧騒の世界を離 れた静寂の境地に, 独り自から遊化しているので, 外道 異端の輩に申すに及ばず，悪魔鬼神といえども，その威 に畏れて寄りつくことはできない。正法とはこのような ものである。如来の正法を嫡伝した真の仏弟子は，仏祖 と同じく決定無畏の正法輪を転ずる。いま，如来正伝の 仏法たる最上禅は円教であり，頓悟の法門であって，西 天二十八祖，東地六代を伝承してこの私に到っている。 諸君，疑問があるなら遠虑なく質問したらよからう。私 がこういらのは我見我慢を湜ましうして，好んで他と論 争をしょうといらのではない。諸君が円頓の法門に対し て疑問を抱いて，これを決着せずに放置するならば，い かに苦行修練して見たところが，結局は断見常見の穴に 落ち，ついに解脱自由の妙境洷着することが不可能に なる。それが気の毒でたまらないから口やかましくいう のである。

ஓ伀道修行には，まつ，妄想分別の先入観を捨てて, 我執法執の住着を離れなければ，是も是ならず，非も非 ならず，事物の真相を見得することが不可能である。こ こが大乗円頓の妙法を聞く上に最も大切なところで，最 初の一歩を䛊まると千里の隔りができてしまう。大乗円 頓の教光には男だから成仏するとか，女だからでき奴と いった差別はつけられていない。しかし，例克男でも邪 悪の心を起すと，直ちに無間地獄に落ちてしまうぞ。

22私は年少の頃から仏門に身を投じて，経律論の三蔵 を研究してきたが，その態度はどこまでも学者であり教 者であったため，自己に回光返照して大安心を得ること ができなかった。积尊にまのあたり叱責された思いがし たが，今日，その当時を思い返えして見ると，従来，こ れまでの自分が仏教の根本精神を忘れて文字言句の末に 走り，多年，他国の風塺堆裏さにさ迷っていたことは実 に慚愧に堪えないものがある。幸いにも，曹渓山で六祖 慧能に参ずることができて，自己の本家郷㴏家䅼坐し て，今日あるを得たものである。

20邪悪の性質の者は, 経論を読んでも，説法を聞いて も, 名相言語に拘泥して素直に如来の妙法を領解するこ とができず，自分の邪推な知解分別でこれを錯会し，つ。 いに円頓の法則にも違背する。だから，いつまでも生死 
の苦境をさまよい，善星比丘の極き極端な者まで出て来 る。邪悪な錯解者というものは，声聞と縁覚の二乗を見 惑思惑の煩悩と断じ，そして克已して精神努力はする が，自利のみを事として他利の道心が少しもない。

勾を開けば空で何もない。ところが無智というもの は情けないもので, その空拳の法門に何にか有難い仏様 でも拈られるょうに，それ住着してしまう。子供比月 を教觉て見ると，月を指す母親の指を見て月を見ないよ らに, 説法の言説や経文の文字に拘泥し, 真如の月を標 示するための指に外ならないことを認識しょらとしな い。発心して修行の功徳を積んでも，目的が間違ってい ては何んの役にも立たないばかりか, 主観の根, 客観の 境と二見相対の法を立てて, 如来真実の相を自から見兄 ぬよらにしてしまらのである。

区一切万法は無自性不可得であるといら真実相を了悟 すれば，いかなる悪業罪障も本来空である道理が信解さ れて，大安心を得るものであるが，その了悟ができない らちは万境に心が転じて迷いに迷いを重祊，悪業に悪業 を重悋て宿積となっていく。その償いに追われて間断な く苦しめられている。諸君, 宇宙の大道は随所に現わ れ，正法は古今に流伝していても，これを信んじ，これ を修行しなければ，生死の苦㥗を解脱して涅槃の妙薬を 得ることはできない。真の大丈夫ならば，如何なる欲火 に相遇しょうとも焼失することはない。例党ば，泥中か ら生じて咲く蓮華のようである。草，勇施という出家は 二重禁戒を犯して深く懒愧したとき，仏の教えに深く思 惟して忽古無生忍を悟って成仏し, 現汇宝月如来となっ て西方常光国淿就す。仏の知見を開くことが如何に大 きな功徳であるかを，諸君法知るべきである。

凤年ま，私の説く教光はとりもな怙さず釈尊の説法で 㐫り, 祖師の訓㛛であり, 大乗円頓の如来禅であるが, この説を信解する者の少ないことは歏かわしい。諸君は ただ，重禁戒を犯す時は仏道修行の障碍となることを知 っているが, 如来が罪障不可得, 畢境, 無自性であると いう妙理の班訣を開かれるということを知らないである う。ここに二僧がいて，一人浪邪媱を行ない，一人は殺 してしまった。二人は悔恨して優婆離尊者にとの罪の判 定を愁願をしたが，尊者は情状酎量せずに，唯だ深く擮 悔して三尊道の苦患を免礼るように祈るがよいといっ た。これを聞いた維摩居士は，罪性に実有の見を生ずる は妄想を重㸚るものだ。罪性は畢境して内にもあらず, 外にもあらず，中間にも㐫らず，ついに不可得のもので ある。この不可得を証す扎ば人間は本来解脱しているこ とが判るはずだといって, 先きの判決を覆してしまっ た。そこで二僧も居士の説を聞いて疑団を破り，各々仏 見知を悟ることができたという。不思議解脱の法門は一 句一偈を聞くだけでも, 長い間の修行に勝っているから である。
39伀教の法門は八刀四千と称せられているが，この不 思議解脱の法門である如来円頓の教えは, 法門中の王で あり, 最も高尚で, 最も勝れた教えである。三世の諸仏 や歴代の祖師方はすべてこの法門を証得され, その不思 議解脱の力を以って, 自由自在に機に応じて衆生済度の 妙用を意の如くされた。私は曹渓の六祖慧能の正伝の仏 法を伝え, 如来宝珠にも比すべき最上の法門を領解する ことができ, 諸仏諸祖と同証して, 不思議解脱の法門を 信受奉行することを喜んでいる。諸君，仏法というもの は我執や法執など, 一切の執着を離れて情意の束縛を脱 したときに，はじめて真の仏法が手に入るものである。

(2月光は熱し, 日光は冷やかであることは万古不変の ものであるが, もしも, 神変不思議の妖術を心得た悪魔 がいるとして, 日光を冷却し, 月光を灼熱させることが できたとしても，その悪魔が如来の真説を打破するとい うことは, 到底不可能なことである。この道理を知らず して正法を誹謗し，これを妨害せんとする彗は，恰もカ マキリが手鎌を振り上げて車の轍を拒むようなもので, カマキリの注らが反って曳き殺されてしまう。巨体の象 は大道を真直ぐに前進して, 決して小鬼の飛び廻る野山 の小径を步かないように, 真の正法を大悟した者は知見 宏大にして，名相言語の末節に拘束されないものであ る。諸君たちは管見から大乗円頓の如来禅を誹謗してい るが, 実に気の毒でならない。天下の参禅諸君, 私は諸 君たちの疑団を解き，不明の点を決断してやるから， 今, 直ちに私の門下に来れ, さあ, 速やかに来って私と 問答をし，そして疑問を解け。

この「永嘉証道歌」から, 本庭園の細部構成, 及び名 称についてその関係を照合してみると，まづ「法身覚了 無一物, 本源自性天真仏, 五陰浮雲空去来, 三毒水泡虚 出没, 証実相無人法。」(法身覚了すればす無一物, 本源首

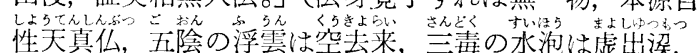
実相を証す机ば人法無し。）に基き，「五陰の浮管は空 去来」を五老峰に，「些毒の水泡は虚出深」を池泉の三 島に配当して水位を高くしている。「獅子吼無畏説, 百 獣聞之皆脳裂, 香象奔波失却威, 天竜寂聴生欣悦。」( 獅

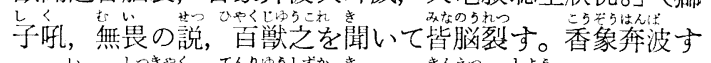

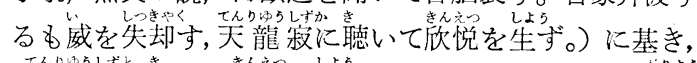

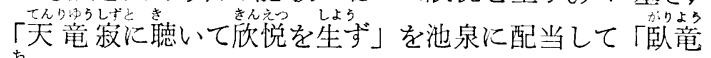
池」と名付けている。「入深山住蘭若, 岑峑幽迫長松 下, 優遊静坐野僧, 家閴寂安居実潇酒。」(深山に入口籣若

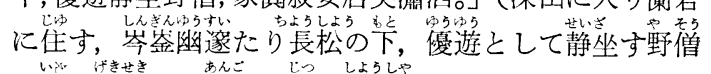

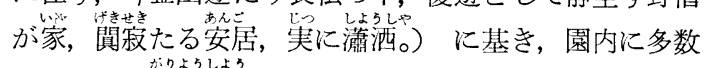
の松を植光臥竜松と名付けて表現している。「争似無為 実相門, 一超直入如来地, 但得本莫愁末, 如浄瑠璃含宝 月, 我今解此如意珠, 自利利他終不歇。」(争でか似かん 無為実相の阴, 一超直入如来地なるに, 但本を得て本

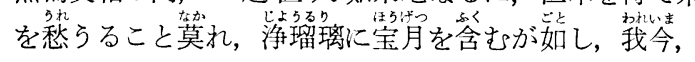


此の如意珠を解す,自利利他終に歇きず) に基,き池泉の 中央に大きく，対岸の観音殿へ(1)亭橋を架け「一超直 只如来地なるに。」を表現している。また，「一性円通 一切性, 一法徧含一切法, 一月普現一切水, 一切水月一

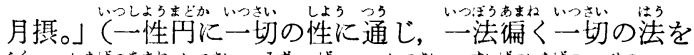
含む, 一月月晋く一切の水に現じ,一切の水月一月に掑す。) に基き，観音殿を「水月場」と名付けている。さらに 「吾早年来積学問, 亦曾討疏尋経論。分別名相不知休。 入海算沙徒自困。卻被如来苦呵責。数他珍宝有何益。従 来踰蹬覚虚行。多年抂作風塵客。」(㕶, 章年上り㔖来, 学 䉍を皘み，赤曾て疏を訪ね，経論を尋ぬ，名相を分別し て, 休することを知らず, 海に入りて, 沙を算えて等に 首から望す，却って如来に苦に阿責せらる，他の珍宝を 数えて何んの益があると, 徒来踰蹬として虚りに行ずる ことを筧中，䇟年拉て風鹿の茖となる。）に基いて「春 帰家」(2) と書き，その遗幅は永保寺に保管されている。

\section{註}

(1) 亭橋は無際橋をはじめとして西芳寺の邀月橋, 常在 光院の楓橋亭, 東山殿の龍背橋, 東福寺の通天橋とつく られた。（室町時代庭園史 P 481）

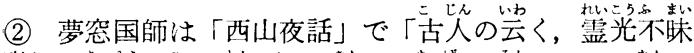

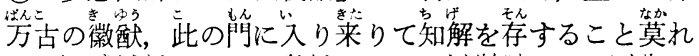

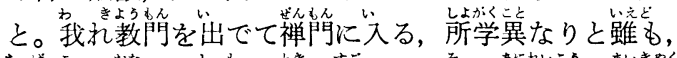

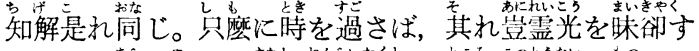

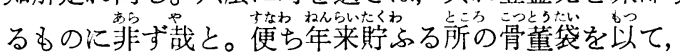

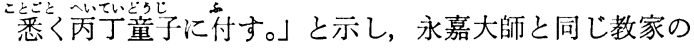
出身であったことを述べている。（国訳禅学大成 第23 巻 P 199)

\section{3. 考 察}

本庭園の主題を「臨済禅の基本思想」として「長皊の 工夫」のためとしたが, 夢空国師は嘉元 3 年 (1305) 10 月に高峰顕日から印可を受けた後, 頓悟した所を大切に 保護していく長養の工夫の時期であった。しかも，延慶 2 年（1309）12月，書簡を高峰に送って「道価が若しわ が老和尚（高峰）より下位に在らば，肯て出世（官寺の 住持になる) せず，ただ閑を守って，草木と俱に腐ちん ことを要すす。といら覚悟を吐露している。さらに, 夢中問答第34段澺とは祖意なり, 祖意とは人々具足 の本分底なり。句は五家の宗風手段なり意は根本なり, 句は是れ枝葉なり。然らば則ち初心の学者は先づ祖意を 参得すべし, 句下に死在すべからず。古人意を得て後三 十年, 五十年, 綿密に練磨して旧業宿障をつくすを, 長 養の土夫となづけたり。」と述べている通り, 土岐川に 臨んだ景勝地に庵を建て, 祖意である「臨済禅の基本思 想」を参得し、「長薏の工夫」を計ったものと考兄られ る。
「土夫」について，夢中問答第56段でつぎの如く述べ ている。「土夫と申寸事は唐土の世俗のことばなり，日 本にいとま之いへる語们同じ，一划のしわざに通ぜり。 耕作は農人の工夫なり，造作は番匠の工夫なり。かやう の俗言によせて道人の仏法を行ずる工夫と名けたり。本 分の工夫をなす人，万事の中か工夫の中かへだつべきな し。中略。さらば穾に道心西る人は，今は坐禅の時なら ずとて，いたづらに光陰をわたることあるべからず。契 飯，著衣，看経，誦呪，東司に功き，後架にいたる，一 切の所作所為の処，臬に交はりて礼をなし，人に対して 物語りする時る，本分の工夫をわすれざる人あり。かや らなるをば万事の中に工夫をなす人と申すべし。中略。 古人の云はく, 山河大地, 森羅万衆, 悉く是れ自己な り。若し能く此の旨を得好机工夫の外に万事なし。」 と。さらに, 夢中問答第48段に「坐禅修行と申寸ことは 禅門ばかり用うる事沈らず，顕密の諸宗にもあかせ り，乃至小乗外道の法にもあり。坐禅といれる語は同じ けれ共, 其の旨趣各ことなり。中略。浄土宗の坐禅は十 六想観等なり。盧山の遠法師等は此の行を専らにす。」 と。このように，「長養の工夫」は「坐禅三昧」をし， 「臨済禅の基本思想」を参得する意味から，「盧山記」 に基いて盧山を縮景した庭園を築き，庵名を古彩，さら に虎奚と名づけられたものと考えられる。

「根本内証の境界」については, 夢中問答第 35 段に 「教の中に仏智を明かするに二種あり。一には根本智,

謂ゆる仏の内証なり。二には後得智, 謂ゆる化他の方便 なり。仏祖出世して教, 禅の法門を説き玉ぶは, 皆是れ 化他の方便なり。然らば則ち禅, 教の学者の, 或は経教 を見或は智識の語に随って，心識の上顸領解する法門は 皆是後智得の分域なり。若し人已に仏の内証の境界契 当せば，後得智を発して利益門汇趣きて，教，禅の法門 を説きて衆生を済度すべし。三世の如来歴代の祖師皆此 式なり。若しいまだ仏の根本智を証せざる人は, 先づ此 の根本内証の境界汇到らんことを思ふべし。若し此の境 界に到らんと思はば，教，禅の分域を超越して始めて到 るべし」と述べている。そして，大乗仏教の妙諦である 「根本内証の境界」を諷詠した「永嘉証道歌」から「庭 園の出典を求めているのは, 永嘉玄覚が教宗の出身で無 相大師といわれ，また，夢空国師も教宗の出身で夢空と 号しているだけに特別の意味を持ち，さらに「夢中問答」 の内容そのものに「永嘉証道歌」が至るところに引用さ れ, 「西山夜話2」では「永嘉大師の罢く, 或は是或は

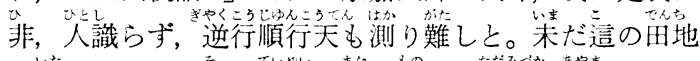
に到らずして，其の体栽を等ぶ者は，管备ら錯るの及に

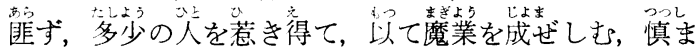
ずんばあるべからず。」（国訳禅学大成第23巻 P 209）と 結語しているところからも，十分に肯定し得るものと考 えられる。 
禅林庭園が思想的背景をもって構成されていること は，夢空国師のつぎの偈頌を見て明らかである。即ち， 「仮山水韻, 繊塵不立峰絺峙。滑滴無存澗瀑流。一再風 前明月夜。箇中人作箇中遊。」（国訳禅学大成第23巻 $\mathrm{P}$ 166）と詠じ，この築山に対して遊ぶ人は，この中の 事 を知った人が遊ぶといっている。

国師年譜の正和二年（1313）には「同門の元翁本元等 と共に遠汇を経て，美濃長瀬山に隠居する。」記され ている。これは高峰顕日が夢空国師を上野の長楽寺(3(4) に住せしめようとしたから, 美濃の長瀬山に隠居したと いわれている。国師年譜には書かれていないが，夢空国 師は美濃国主土岐頼貞の開基で，無学祖元を開山，高峰 顕日を第一世として開創された定林寺に第二世として入 寺していることが，土岐市史(5の「太白和尚鴭嗅集 ${ }^{6} 」$ にある定林寺第四世笑渓妙虎の偈頌で明らかである。

さらに，同門の元翁本元が土岐頼貞の招請により，先 代土岐光定の納骨と三十三回忌の法事(7) と, 寺内に塔頭 の普照庵を創建して, 開山無学祖元像と霊骨を納めてい る。土岐光定の三十三回忌は正和元年 (1312) であるか ら，夢空国師年譜に事実の相違が見られることになる。 夢空国師は高峰顕日の命により, 美濃の定林寺に入寺 し，同道した同門人は夢空国師を補佐して，その経営に 当ったものであらら。従って, 古奚庵は定林寺の末寺と して建てられて, 夢空国師の「長養の工夫」を専らにす る所であると考えられる。このことは，これ以後の土佐 の吸江庵, 相模三浦の臥龍山泊船庵, 上総の退耕庵な ど，いずれも門を閉じて客を謝して専ら長差の工夫をし ている事実を見ても明白である。

重森三玲は「土岐氏の居館時代の作庭 園を考察しているが，当時の土岐家の防禦状況について は，「土岐市場を中心として，西北に哚深沢城を築き北 は本城神篦城（鶴ケ城）あり釜戸山は恵那郡を扼し，東 には宇留輪 (市原城) 猿子, 尾里, 萩原の各城殆んど相 連なり, 南の大手には猿子城あり, 西汇富, 浅野, 高田，多治見と要害を構えたもの。」(土岐頼兼公 P 118) とあって，長瀬の地に土岐氏居館の記録は見当らない。

夢空国師に影の如く随って諸国を遍歴した元翁本元の 「仏德禅師語録」には「虎渓山居偶作」として，「問道 参禅都罷休。癡熟徹底拙於鳩。博山兏陷夢魂断。一蹈々 翻黄鶴楼。」。「鏡面新開池水清。前峰倒影入波心。丹青 不及王維手。相対無言到夜深。」。厂冥心危坐一僽榻。雲 尽水清月在池。不許蒼龍能至鍳。夜深呼杖歩前垟。」( P 30〜31）の三偈を載せ，さらに「雨中対假山懐夢空和 尚」として「絲々春雨織人愁。滴々四篬晚未休。遗吾仏 法無多子。大小石頭水韻幽。」(P22～23）と賦している ところからも，本庭園が夢空国師による作庭であること が明らかである。
言

(1) 玉村竹二著, 夢空国師, P 41

(2) 西山夜話は夢空国師が南禅寺に入寺した際，応機接 物，門弟子の問に答えた法話を収録したもの。

(3) 仏国禅師語録巻下「正和三年甲寅, 師住巨福山建長禅 寺。次年乙卯退㷌雲嚴。師住福山招夢空住上野長楽。空力 辞到濃州長瀬卓庵古渓。」（大正新修大蔵経第80巻 P 283） (4) 夢空国師語巻下, 天龍開山夢空正覚心宗普済国師年 譜「正和二年癸开, 既出龍山未有做往也。且将壊所居之 菓施之浄居以成僧寮。以故暫僑浄居。或者告。遠濃二州 或海隅或山阿皆可幽栖也。師意未肯。時仏国在浄智欲招 師令住上野長楽。有僧預告師。師将避之。潜出浄居先到 遠州。元翁不二祖用等七八人偕来。私謂。苟有適意則宜 以其処為緣遇之地。徐到濃州長瀬山。略。」(大正新修大 蔵経第80巻, P 486)

(5) 土岐市史「瑞雲山定林寺略歴」（P 219） 定林寺開山

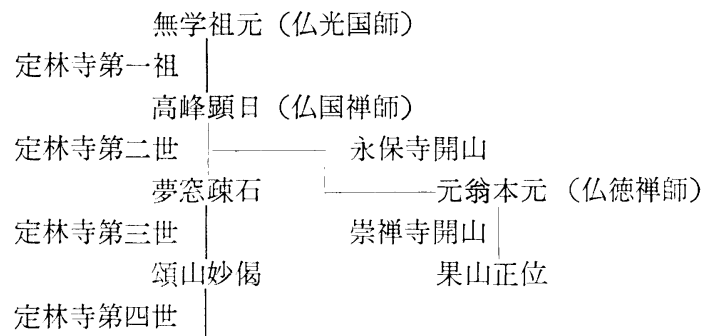

笑渓妙虎

(6) 太白和尚鴉嗅集「虎笑渓住定林諸山，地号土岐。師 乃仏国四世。無相三世。現住永明, 祥光, 瑞雲, 普照皆 塔名。秦氏失鹿。高才疾足先得焉。古公居岐, 流風遗 俗, 有存者, 礼楽当近三代, 干戈既復太平, 某法社湖, 宗門九哲，分座禅林風月。脱脱空仏国乾坤。無相之道三 伝。喝雷棒雨。下略。」（土岐市史 P 220）

(7) 仏德禅師語録「為噯州光公三十三回忌土岐存考請, 规建定林寺普照庵開山仏光祖師像升舎利入仏国祖師䨝骨 及光公骨，南董入奏殿閣凉生脱白露浄今古現成棒骨云前 隠州公禅定門只亭者箅力柱不国家撫育万民攘却臣冠独奮 住声負沖天気宇不戦届人兵亦憑者箇力到処施威草偃風行 動干戈坐致大平丈夫之中丈夫俊英之中俊英一息不来三十 三居諸荏莪才華更只箅不壊底元物满落々落々磨王椱偉哉有 克家之子新建浮図表誠今日斯辰安圆之下略」（P 12 14）

(8) 土岐頼兼公「隠州光公は頼貞の父光定である。光定 は弘安四年七十五才を以て卒しておればその三十三回忌 は，花園天皇の正和元年であり，頼貞四十二才である。」 (P 139)

(9) 日本庭園史大系巻三, 鎌倉の庭 $(-)$, 永保寺庭園 ( $\mathrm{P}$ 138 139)

\section{4. 結 語}

本庭園は，古奚庵開祖夢空国師が，悟道後の「長差の 工夫」のため，庭園の主題を「臨済録」から「臨済禅の 
基本思想」，構想は「盧山記」から「坐禅三昧による巳 事の究明」，構成は「永嘉証道歌」に基いて「根本内証 の境界」を表現した, 廻遊式築山林泉の臨済宗禅林庭園 であると考察する。

\section{引用参考文献}

1）佐藤泰舜校訂 夢中問答 岩波書店 昭和 49 年

2）大正新修大藏経刊行会 大正新修大蔵経第 47,51 , 80 巻, 大正新修大蔵経刊行会, 昭和36年

3）堤久雄 洪䧌山石庭の主題と形成の時期

4）笹原佗介土岐頼兼公 土岐頼兼公顕彰会 昭和13年

5）土岐市史編纂委員会，土岐市史，土岐市 昭和45年

6）古田紹欽訳註 臨済録 角川文庫 昭和37年

7）加藤咄堂 碧嶷録大講座 平凡社 昭和14年

8）沢木興道 禅とは何か一証道歌新釈一 誠信書房 昭和 48 年

9）重森三玲 日本庭園史大系巻三，鎌倉の庭 $($ 社会 思想社 昭和46年

10）元翁本元 仏镘禅師語録 虎溪山永保寺 昭和 6 年

11）玉村竹二: 夢空国師 平楽寺書店, 昭和33年

12）柳田聖山 臨済の家風（日本の仏教 8) 筑摩書房, 昭和 43 年

13）仏書刊行会 大日本仏教全書 仏書刊行会 大正 2 年

14）外山英策 室町時代庭園史 思文閣 昭和 48 年

15）川瀬一馬 夢空国師 禅之庭園 講談社 昭和 43 年

16）堤久雄 洪隠山石庭の主題と形成の時期, 造園雑誌 第35巻 2 号 昭和 36 年

17）国訳禅学大成編輯所, 国訳禅学大成第23巻, 二松堂 書店，昭和 4 年

\section{Summary}

According to the annual table of Muso-kokushi, in showa 2 ( $\mathrm{AC} 1313$ ) he came to the Totomi province from the Jogo-ji temle, along with his six or seven follow-practitioners, such as Hongen Gen-o' Kokumon Funi, So-yo and so on, and finally reached Mt. Nagase whose solitary scenery attracted him a great deal. It is said that he built a hermitage here and called it Kokei (Ancient Valley) against the intention of his master Kennichi Koho to make him the chief monke of the Choraku-ji temple in the Kozuke province.

But according to the history book of Toki city, unlike the above annual table, Musokokushi is the second chief monk of the Jorin-ji temple whose lay founder is Yorizane Toki, lord of the Toki district, and invited found is Sogen Mugaku, and the first monk founder is Kennichi Koho. Consequently, the Kokei-an is considered to have been built as an annex hermitage of the Jorin-ji temple and the six or seven fellow-practitioners of Mushokokushi came to help this kokushi with his managing the hermitage.

Here Muso-kokushi applied himself to the "long strict practice after enlightement", while Hongen Gen-o and Myogen Jusan were engaged in the temple affairs of the Jorin-ji temple. Especially the former, invited by Yorisaa Toki before the annual table of Muso-kokushi, accepted the bones of the predecessor Mitsusada Toki and performed a memorial service at the 33rd anniversary of his death. Furthermore, he built another annex hermitage named Fuso-an where the image of the founder Sogen Mugaku was located and his bones were dedicated. This memorial service was performed in Showa 1 (1312) and the next year but one the Kannon temple of the Kokeian was built.

About the situation of defence of the then Toki clan, Sanrei Shigemori, a researcher of "the gardening when the Toki clan was in the mansion" and garden of the Eiho-ji temple, says: "with the Tki market as a center, they built the Fukazawa castle in the norh-western part and the Tsuruga castl in the northern, Mt. Kamado commanding the Ena district. In the front place of the south there was there was the Mashiko castle; in the west there were the positions of strategic importance, Such as Otomi, Asano, Takada and Tajimi. "(Cf. Toivorikane$k o$, p. 118)." This shows that there was no record that the Toki clan had the mansion on Mt. Nagase.

In the Buttoku-zenii-goroku by Hongen Gen-o there is a passage entitled "casual work on Mt. Kokei": the surface of a mirror opehs newly and the water of a pond is clear..." This means that Muso-kokushi built a garden then in such a spiritual realm.

The Summury of the Garden of the Eiho-ji Temple The subject of this garden srows the long strict practice after enlightenment..... the fundamental thought of Rinzai Zen based on the Rinzai-roku... by Muso-kokushi, founder of the Kokei-an; the conception of it shows the thorough realization of true Self through zazen stemming from the Rozan$k i$ (A Guide of Lu-Shan); the structure expresses the realm of the original enlightenment based on the Shodo-ka (The Song of Enlightenment) by Yokadaishi. This is the garden of the Rinzai Zen monastery where we walk about trees and springs. 